\title{
Self-employment as a Non-standard Form of Employment in the Czech Republic and in Poland
}

\author{
Anna CIERNIAK-EMERYCH ${ }^{1}$, Eva HAMPLOVÁ ${ }^{2}$ \\ ${ }^{1}$ University of Economics in Wroclaw, Wrocław, Poland \\ aemerych@wp.pl \\ ${ }^{2}$ University of Hradec Králové, Hradec Králové, Czech Republic \\ eva.hamplova@uhk.cz
}

\begin{abstract}
The Modern companies, faced with high volatility and the associated unpredictability of their operating environment, often approach the challenge by changing the character of their relations with employees. Flexibility of employment as a strategy of response based on non-standard or alternative models of employment has become an established standard in business practice. A good example of this new approach is self-employment or disguised employment. Observation of business practice suggests that companies are more and more interested in maintaining a pool of contingent workers loosely associated with traditional company structures and employed for specific tasks. In this context, the study presents an analytical evaluation of self-employment defined as a formal statement of contractual independence. The aim of this paper is to portray the character and the wealth of approaches in business perception of the self-employment category, particularly in association with business operation practices observed in the Czech Republic and in Poland. In addition, based on the results of a pilot empirical study, the study addresses a partial objective of examining the interest in this type of contractual employment among persons entering the job market.
\end{abstract}

Keywords: Self-employment, Czech Republic, Poland

\section{Introduction}

Modern companies, faced with high volatility and the associated unpredictability of their operating environment, are often required to change the nature and the quality of their relations with employees, with marked preference for departure from the traditional model of employer-employee association of interests. The traditional model of employment was based on the paradigm of permanent employment with dominance of stable employment relations and assumed full-time employment, and at the same time - providing formal confirmation of employment status for workers. This approach is now being replaced by the new category of flexible employment construed on a framework of non-standard and alternative forms of employment.

Professional literature presents several categories of non-standard employment which can be regarded as examples of flexible employment strategy, such as 
contracted work, seasonal employment, employment based on civil contracts (e.g. fee-for-task), and others. It must be noted that those forms are not mutually exclusive, and individual employment may incorporate features and characteristics of one or many of the above [11, pp. 56-80].

The self-employment phenomenon is a specific form of non-standard employment. It involves delegation of specific tasks and assignments to independent contractors. One of the most notable differentiating features in this context is the sharing or roles played by self-employed individuals - they are employed both in the role of owners (typically representing the SME sector) and of work duty performers.

The adaptive capacities of both workers and employers underlined in the context of promoting flexible forms of employment (including self-employment) are considered to be one of the most important elements of the third pillar of the European Employment Strategy (EES) formally adopted in 1997 in Luxembourg. At the same time, it should be noted that, in 2014, Poland ranked fifth among the European Member States in self-employment (measured as a ratio of self-employed in the total number of employed), with a score of $18.2 \%$. The Czech Republic ranked fourth, with a similar score of $18.9 \%$ ) [3, pp. 104-105].

As observed by J. Wiśniewski: "The roots of self-employment should be sought in the promotion of the entrepreneurship ideal, as the increased interest in selfemployment is perceived to be a sign of socially accepted attitudes of industriousness and creativity. Human entrepreneurship and investing in one's own attributes and potential are seen as a radical departure from the traditional attitudes of submission and servility" [18, pp. 36-41].

Taking into account the above observations, this study aims to examine the characteristics of self-employment and the general perception of self-employment as a category of gainful employment, particularly in association with business operation practices observed in the Czech Republic and in Poland. In addition, based on the results of a pilot empirical study, the study addresses a partial objective of examining the interest in this type of contractual employment among persons entering the job market.

The above objectives were addressed by the use of literature studies, analyses of statistical data and results of proprietary pilot studies of self-employment as a viable form of employment considered by students of senior years of master studies. A broader overview of research methodology will be presented in the next section of this paper, followed by presentation of conclusions from literature studies and analyses of results obtained in the course of empirical research (both third-party studies and own research).

\section{$2 \quad$ Research methodology and literature studies}

\subsection{Methods of research}

For the realisation of the study objectives, the following methods were employed:

- Review of professional literature and applicable legal documents, 
- Overview of third-party empirical research on the subject at hand,

- Presentation of statistical data derived from formal reports obtained from statistical offices,

- Presentation of results obtained from a pilot proprietary diagnostic poll on the interest in self-employment as a viable form of employment considered by students of senior years of master studies.

The proprietary pilot empirical study was conducted in the years $2016-2017$ and took the form of a poll survey targeting nearly 70 respondents (as part of a research project conducted by the Department of Labour and Capital at Wroclaw University of Economics, and managed by a co-author of this paper, A. Cierniak-Emerych).

The survey contained both closed-type questions with variants of responses, and open questions. Opinion polls were anonymous and confidential. Analytical evaluations were made with regard to 10 most beneficial and 10 most detrimental properties or qualities of self-employment. The list of benefits and detriments used in the study was construed on the basis of third-party research and own observations. In addition, the respondents were free to supplement the list by other properties and qualities deemed important in the study's context. Respondents were also asked to present their own conclusions on the positive dimensions and the limitations of selfemployment. Apart from questions targeting directly the scope of issues under study, respondents were also asked to present their opinions, interests and expectations towards their future gainful employment. Respondents were asked to evaluate each of the elements from the list of attributes from their own perspective and select the appropriate response from the following: very important, fairly important, neither important nor unimportant, rather unimportant, entirely unimportant.

The surveys were also accompanied by open-type interviews with those of the respondents who agreed to participate in this segment of research (16 persons). This stage of research employed the methodology of IDI - in-depth interview - as described (among others) by S. Kaczmarczyk; this type of interview is an example of a direct instrument of opinion-poll measurement in which the respondent is an active object of measurement and which is characterised by direct communication between respondents and researchers (i.e. takes the form of a conversation) [12, ff. 252].

The results presented herein concentrate solely on those expectations which were deemed by respondents as 'very important'. The entire range of results will be presented and utilised in later publications. Below are the results of opinion surveys collected in the years 2016 - 2017 among nearly 70 students of Wroclaw University of Economics, Department of Engineering and Economics, who took the subject of 'technological entrepreneurship' as part of their master course studies. The reason for limiting the survey to recipients of this particular subject of studies lies in the fact that skills and knowledge required in the formation of own enterprise are the core of competence addressed by this course.

The results presented below cannot be regarded as statistically significant, and should only be perceived as a preliminary examination of the validity of the adopted research assumptions. 


\subsection{Self-employment and the flexible model of employment, in the light of professional literature}

The existing and fairly rich scope of professional literature on the subject of selfemployment provides a wealth of diverse determinants and characteristics deemed of essence for the practical operation of the contemporary model of flexible employment. One of the most popular postulates is the concept of a 'shamrock organisation' flexibility of employment, developed by Ch. Handy. According to this concept, company employees may be classified into three fundamental segments symbolised by three distinct 'leaves' of the shamrock structure of organisation $[10$, pp.75-97]:

- The first leaf is composed of the core staff, i.e. persons that define the core competences of the organisation. This segment is also referred to as the professional core. Employees in this category hold knowledge that differentiates the organisation from the others,

- The second leaf represents persons employed on short-term contracts,

- The third leaf represents contingent work force, employed in response to increases in demand.

Similar attempts at structuring the present changes to traditional models of employment can be found in other publications. For instance, J. Atkinson [1] postulates a method of classification into the following 'layers of employment': basic employees, core personnel, and peripheral employment. As a result, companies display a tendency to separate their employment structure in two distinct groups permanent (stable) employment and peripheral (unstable) employment, resulting in a stark distinction between stable and unstable workplace assignments and the formulation of a network of external contractors employed by separate economic entities.

For the purpose of this study, the main emphasis will be placed on the latter group of external contractors and on the associated category of self-employment, typically identified with external provision of per-task duties for the company by persons running their own independent enterprises. One point of note in this context is the lack of a unified definition of self-employment, both at national (the Czech Republic, Poland) and supranational level (the European Union). For example, as pointed by Lasocki B. and Skrzek-Lubańska M., Austrian regulations define self-employment as independent gainful employment; this service can take many forms, such as: microentity (and its extreme form of a one-man company), personal partnership (civil-code, general or limited partnership), capital venture, liberal profession contracts or funds. Belgium, in contrast, identifies self-employment with independent enterprise ran for profit, while the law of the Netherlands perceives it mainly through the provision of subcontracting services for other companies [13].

Based on the above deliberations, it may be observed that self-employment regardless of the adopted legal definition of the term - should be interpreted in the context of the entrepreneurship idea, and specifically in relation to the rapid formation of small and micro enterprises. 
It may also be useful to note at this point that self-employment is often perceived as a measure of workforce flexibility, since it may reduce the unemployment rates and - at the same time - serve as a source of additional income for state budgets (taxation). Formation of one-man enterprises may also lead to creation of new jobs, as micro-entities may eventually expand into larger structures. The above outlook on the benefits offered by self-employment can also be observed in the EU documents where this particular category of employment is clearly perceived as a warranty of balance on the labour markets.

It must be remembered, however, that self-employment is not without faults. The most important disadvantages of this form of employment include: poor stability, sharing in the risk of business operation, lack of the broadly defined security of employment, bearing the full cost of individual development, security of work conditions, etc. [7, p.261].

As already noted, both the Czech Republic and Poland are representatives of states with the highest ratio of self-employed individuals [3, p.104.]. For this reason, the following sections of this study will concentrate on the presentation of the phenomenon from the viewpoint of these two EU Member States.

\section{Self-employed Persons in the Czech Republic}

\subsection{Definition of Self-employment}

According to Act No. 155/1995 Coll., on Pension Insurance, as amended, the following are considered self-employed [4]:

- they carry out an independent gainful activity, or

- they co-operate in carrying out an independent gainful activity, if the income from this activity and the expenses incurred by it can be divided to this person pursuant to Act No. 586/1992 Coll., on the Income Taxes, as amended,

- they have completed the mandatory school attendance and have reached at least the age of 15 .

An independent gainful activity is understood as:

- the business of farming, if the natural person carrying out the farming is registered pursuant to special legislation,

- carrying out a craft on the basis of an authorization to carry out a craft pursuant to special legislation,

- the activity of a partner in a partnership or general partner in a limited partnership carried out on behalf of this company,

- carrying out an artistic or other creative activity on the basis of copyright relations.

Since 1 January 2004 the difference between a major and subsidiary independent gainful activity has been distinguished. An independent gainful activity is always 
considered major unless the conditions for a subsidiary independent gainful activity are fulfilled.

An independent gainful activity is considered subsidiary if the self-employed person in the calendar year:

- was employed,

- was entitled to the payment of a invalidity pension or an old-age pension has been awarded to him/her,

- was entitled to a parental allowance or maternity cash benefit or sickness benefit due to pregnancy and delivery if there is an entitlement to these benefits on the basis of sickness insurance of employed persons or cared personally for a person under 10 years who is dependent on the care of another person in degree I (light dependency) or for a person who is dependent on the care of another person in degree II (medium dependency) or degree III (heavy dependency) or degree IV (full dependency), if the person who is dependent on the care of another person is a close relative or lives with the self-employed person in a common household,

- served in the Czech military, unless they are professional soldiers, or community service,

- was a dependent child within the meaning of $\S 20$ (3) (a) of Act No. 155/1995 Coll., on Pension Insurance, as amended (study) Results and Discussion[5].

\subsection{Statistical Data - Self-employment i.e. Natural Persons}

Data on the organizational structure of the national economy are compiled from information kept in the Statistical Business Register. The Statistical Business Register keeps record of businesses, i.e. legal persons, organizational units of the state, unit trusts, and natural persons with the status of entrepreneur.

A business with an identified activity is such a business that according to information from administrative sources or statistical surveys reports economic activity. This economic activity is demonstrated at least by one of three conditions. A unit has employees, pays income tax or pays social insurance. It means that the Czech Statistical Office assigns the code of activity to business entities on the basis of information from other registration sites such as the Tax Office and the Czech Social Security Administration.

In the Czech Republic within the business sector there is a visible difference between the number of enterprises that are registered as business entities and the number of enterprises that exert real economic activity. Natural persons include private entrepreneurs who are in business under the Trade Act (A), agricultural entrepreneurs (B) - natural persons, and natural persons carrying out other business activities governed by special regulations (C). Private entrepreneurs in business under the Trade Act are natural persons with a trade licence. Private entrepreneurs in business under other acts include agricultural entrepreneurs - natural persons, members of professional chambers, and other natural persons whose business activities are governed by separate legal regulations. 


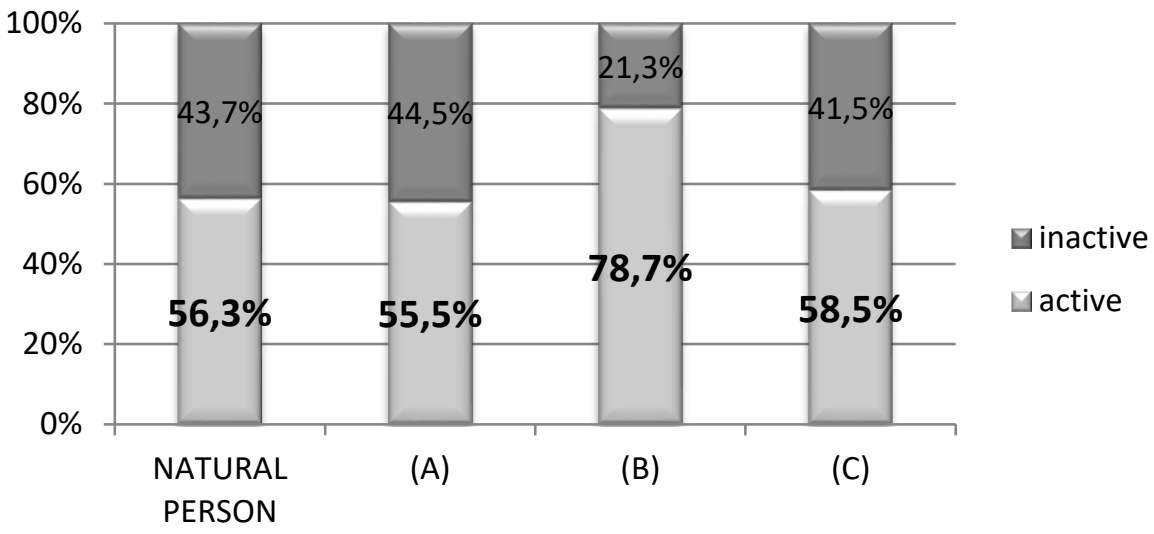

Fig. 1. The Share of Active and Inactive Natural Persons in the Czech Republic 31 12th 2015.

In the Czech Republic within the self-employment sector there is a visible difference between the number of enterprises that are registered as natural persons entities and the number of natural persons that exert real economic activity (see Fig. 1). For their significance, only active natural persons are analyzed.

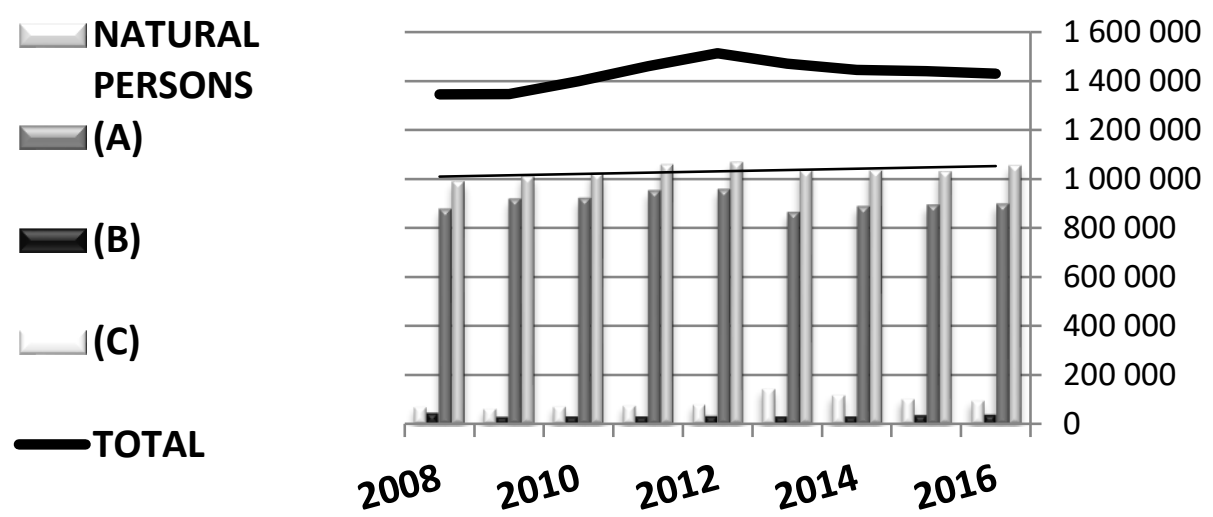

Fig. 2. The Development in the Number of Active Natural Persons in the Period 2008-2016 in the Czech Republic. (A) Private entrepreneurs in business under the Trade Act; (B) Agricultural entrepreneurs - natural persons; (C) Others.

The analysis shows (see Fig. 2) that self-employment represents a high share of the total number of active business units in the Czech Republic (70 - $75 \%$ in the period 2008 - 2016).

Self-employment is represented in the following sectors: wholesale and retail trade; repair of motor vehicles and motorcycles; professional, scientific and technical 
activities; construction; manufacturing; other service activities; real estate activities; accommodation and food service activities [9].

The private entrepreneurs who are in business under the Trade Act (A) constitute a greatest proportion (59-68\% in the period $2008-2016$ of the total number of active business units). These entrepreneurs take advantages of self-realization, independence, flexibility and a higher income than as an employee earns. They are their own bosses, enjoy more tax deductions but on the other hand they risk all their property, assume high responsibility, overcome bureaucratic obstacles, manage a large number of different roles in entrepreneurship and a lot of different skills and knowledge (be a 'jack-of-all-trades'). The natural persons with the status of entrepreneur in the Czech Republic prefer the speed of registration as a freelancer, simplicity of establishment, interruption and finishing of entrepreneurship.

\section{Self-employment in Poland}

\subsection{The character and the manifestations of self-employment and individual entrepreneurship}

In Polish economic practice, self-employment is typically associated with individual entrepreneurship and rendering of independent services for one or many business enterprises [8, p.6]. Article 2 of the Polish Act of July 2, 2004 on freedom of business operation defines individual entrepreneurship as a gainful activity in production, construction, trade, services, exploration, identification and extraction of mineral deposits, and other vocational pursuits rendered in an organised and continuous manner [16].

In addition, the Act provides a definition of an entrepreneur as a natural person, a legal entity or an organisational unit with legal titles endowed on the power of a separate Act, and involved in economic operation under their name. In other words, the Act associates self-employment with entrepreneurial activities of a one-man company. It must be emphasised that professional literature fails to provide a unified approach to the formation of new jobs within the existing self-employment structures (i.e. expansions of one-man companies into larger companies. Some experts state that self-employment should be carried out without additional employment [8], while others believe that self-employed individuals have the freedom to create new jobs [18; 14].

In Poland, perceptions of self-employment are varied. In some cases - as demonstrated in third-party studies - it may (and in fact, often does) lead to pathologies. In particular, employers willing to reduce the cost of employment and driven by the egoistic slogan of 'for my own good', may exert pressure upon their employees to resolve their standard contracts and opt for self-employment to serve their regular range of duties [2, pp. 45-46]. There are also positive examples of practical effects of self-employment, with more and more professional and vocational segments perceiving this form of employment as highly desirable. This effect is 
observable in freelancing professions (lawyers, architects), but can also be found in other vocational segments (e.g. physicians).

As suggested in study results published by the European Commission, at the onset of the second decade of the century, six out of ten Polish citizens up to the age of 25 displayed interest in setting up their own enterprise. At that time, a third of the formally registered companies in Poland were run by persons below the age of 30 . In e-business, this ratio went as high as $85 \%$ [17].

Based on 2016 data, Polish entrepreneurship involves the operation of ca. 1.84 million formally registered companies, of which $96 \%$ - ca. $1.77 \mathrm{~m}$ - represent the small and medium sized enterprise segment. The above figures translate into a $73.5 \%$ share in GDP, with more than a half (50.2\%) generated by the SME segment (30.8\% from micro enterprises, $8.8 \%$ from small companies, and $10.6 \%$ from medium sized companies) [15].

In view of the above, it may be useful to examine the attitudes towards this form of employment among students of senior years of master studies, as the new generation of professionals about to enter the labour market.

\subsection{Self-employment as a viable form of future employment for young professionals entering the labour market - a presentation of findings obtained in a pilot study}

Based on a predefined list of factors that stimulate or deter decisions on selfemployment, and on respondents' suggestions in this respect as well as their voiced preferences in future vocational career, the authors found that the dominant group of respondents were those who - while conscious of the positive effects of selfemployment - expressed their reservations towards this form of employment.

More than a half of nearly 70 respondents, when asked to provide their own suggestions of the positive and negative aspects of self-employment, emphasised the following:

- Potential for self-fulfilment,

- Preserving autonomy of decisions made with respect to future professional development,

- Improved gain (increases in both financial and non-financial returns for service rendered to third parties),

- Potential for pursuing own business objectives and ideas,

- Relative freedom in the choice of time, place, and method of task realisation.

Beneficial properties of self-employment, such as self-fulfilment, professional development, and pursuance of own business ideas, were particularly strongly emphasised by those respondents that qualified for the in-depth interview stage of the study. Persons in that group stressed the view that, based on their own observations and - in part - professional experience (despite being students, some of them had already had the opportunity to practice in their field), rendering of services for a specific employer on a contractual basis would potentially have the effect of limiting 
or even blocking off their creativity and innovation, and would surely have a strong impact on their perceived 'independence' or 'self-reliance'.

The above opinions may rise reasonable doubt, particularly when contrasted with the abundance of arguments offered by professional literature in favour of the view that creativity and innovation are the most preferred qualities of a modern employee. Perhaps one of the reasons for such a negative pool of opinions voiced by our respondents lies in the fact that some of them had already had some 'bad experience' in this respect.

In fact, the reality of Polish business practice shows propensity for employers to perceive persons entering the labour market as a 'cheap workforce'. To make things worse, young professionals are often perceived as wielders of purely theoretical knowledge, and thought to be, on average, devoid of any competence to utilise their knowledge in practice. It must be noted at this point that the above opinion is - or may be - quite detrimental to those professionals who aspire to share their creativity with the employer, but are denied any opportunity to do so. At the same time - and interestingly enough for research purposes - it was the same group of respondents of all the persons included in the study who (based on their questionnaire responses) were steadfast reluctant to engage in self-employment. They attribute it mostly to the lack of financial resources - and sometimes the courage - to undertake the risk of independent business operation. They also emphasised their intent to gain more experience before they are ready to consider the idea of running their own independent enterprise.

The respondents (57 out of 68 included in the study) were adamant in their view that self-employment was largely stimulated by such personal qualities as success orientation, leadership qualities, optimism, mental resilience, and the skill to cope under stress. However, those attributes were indicated as part of general self-image only by 8 out of all the 68 respondents included in the study. For instance, one female respondent had already had extensive practice in creating and selling for profit a wide assortment of decorative products. Incidentally, the same female respondent was the only one to steadfastly assert her commitment to self-employment after completion of her studies.

The remaining respondents, when asked for their expectations towards future vocational career, attributed greatest weighs to such qualities as the adequacy of wages to workload and the sense of employment security. Of the properties deemed detrimental for their will to engage in self-employment, respondents indicated such responses as: risk avoidance, the lack of mental resilience, and the perceived difficulties in making adequate decisions, particularly those related to business. Such attitudes may be quite astonishing among persons who - without exception - are students of senior years in management and engineering of production, specialising in 'Management in Production and Services', where the attribution of knowledge and skills required for the formation and management of own enterprise is considered among the main educational objectives. Entrepreneurial knowledge and skills should not come as anything new for this group of students. On the contrary - they should already be fairly well established, particularly when students are actively incentivised 
to participate in various extracurricular activities to that effect, e.g. those within the framework of academic incubators of entrepreneurship.

\section{Conclusions}

Professional literature provides ample representation of the view that selfemployment offers more opportunities for creative approach for the most skilled individuals. At the same time, practical realisation of these opportunities is closely related to structural, legislative, economic and social determinants that serve to ascertain the perception of self-employment as a viable approach in the distribution of human creative potential for innovation [18]. It must also be remembered that properties deemed of great value for one person may just as well be perceived by others as obstacles that greatly reduce their ability to cope with decision-making challenges and risks of economic operation.

To sum up the results of the pilot empirical studies, it may be observed that the knowledge and the skills required in self-employment are already fairly wellestablished among our respondents as master course students who are about to enter the labour market. However, not all of them - as evidenced in the results - were ready to commit to this type of employment in the near future despite being quite aware of the positive dimensions of running one's own business.

In this sense, the responses obtained in the pilot study failed to corroborate the modern trend in professional literature that associates propensity for self-employment with young age. Perhaps the pilot quality of the study is one of the reasons for such a discrepancy; another reservation may be raised as to the composition of the respondent sample. Hence, the problem under study will require further insight and evaluations, both economic and those in the social dimension. The authors believe that one of the most promising directions for further research is the consideration of cultural determinants of self-employment propensity. This is the chance the authors would like to pursue, based on close cooperation and simultaneous studies by partners in Poland and the Czech Republic.

\section{References}

1. Atkinson J.: Manpower strategies for flexible organizations. Personel Management 16,s. 28-31 (1984).

2. Bąk, E.: Elastyczne formy zatrudnienia. [Flexible Forms of Employment]. Wyd. C.H.Beck, Warszawa (2006).

3. Bąk, E., Grabowska, D.: Zarządzanie Zasobami Ludzkimi w warunkach stosowania niestandardowych form zatrudnienia. [Human Resources Management in the conditions of Non-standard Forms of Employment]. Wyd. UE we Wrocławiu, Wrocław (2016).

4. Collection of Laws: Records of Pension Insurance No. 586/1992, https://business.center.cz/business/pravo/zakony/dprij/, last accessed 2017/09/29.

5. Collection of Laws: Records of Pension Insurance No. 155/1995, https://business.center.cz/business/pravo/zakony/duchodpoj/, last accessed 2017/09/29. 
6. Czech Statistical Office: Statistical Yearbook of the Czech Republic 2016. https://www.czso.cz/csu/czso/statisticka-rocenka-ceske-republiky-2016, last accessed 2017/09/30.

7. Drela, K., Sokół A.: Formy zatrudnienia w małych i średnich przedsiębiorstwach. [Forms of Employment in Small and Medium-sized Businesses]. Jak zatrudnić pracowników. CeDeWu, Warszawa (2011).

8. Grywińska, J.: Samozatrudnienie jako nowa forma zarobkowania. [Self-employmend as a New form of Employment]. Wyd. Wszechnica Podatkowa, Kraków (2007).

9. Hamplová E., Provazníková K.: Small and Medium-Sized Enterprises and their Position in the Economy of the Czech Republic. In: Proceedings of the 24th International Business Information Management Association (2014).

10. Handy, Ch: Wiek przezwyciężonego rozumu, [The Age of the Fallen Mind], Business Press, Warszawa (1998)

11. Hejun Z.: Elastyczność popytu na pracę w Polsce aspekty prawne. [Job Demand Flexibility in Poland, legal aspects]. [w:] Kryńska E. (red.) Elastyczne formy zatrudnienia i organizacji pracy a popyt na prace w Polsce, IPiSS, Warszawa (2003).

12. Kaczmarczyk S., Badania marketingowe. Metody i techniki. [Marketing Research. Methods and Techniques]. PWE, Warszawa(1999)

13. Lasocki, B., Skrzek-Lubańska, M.: Samozatrudnienie w Polsce - problemy definicyjne, dostępność danych i ich interpretacja. [Self-Employment in Poland - Definition Problems, accessibility and interpretation of data]. Wiadomości statystyczne, 7, s.3-4 (2016) http://stat.gov.pl/files/gfx/portalinformacyjny/pl/defaultaktualnosci/5982/7/17/1/ws_07_20 16_01_boguslaw_lasocki_malgorzata_skrzek_lubasinska_samozatrudnienie_w_polsce_ _problemy_defi.pdf, last accessed 2017/10/08.

14. Puzio-Wacławik, B.: Samozatrudnienie jako element systemowego wsparcia rynku pracy w Polsce. [Self-employment as an Element of System Suport for the Job Market in Poland]. Studia Ekonomiczne,145,(2013), Uniwersytet Ekonomiczny w Krakowie http://www.ue.katowice.pl/uploads/media/17_B.Puzio-Waclawik_Samozatrudnienie_jako ....pdf, last accessed 2016/04/11

15. Raport o stanie sektora małych i średnich przedsiębiorstw w Polsce, PARP, Warszawa (2016).

16. Ustawa o swobodzie działalności gospodarczej [Freedom of Business Activity Act] z dnia 2 lipca 2004 r. Dz.U. 2004 nr 173 poz. 1807z późn. zm..

17. Wesołowska, E., Stawiają na siebie. [They count on themselves]. Dziennik Gazeta Prawna 1 VIII (2011).

18. Wiśniewski, J.: Istota samozatrudnienia. [The Nature of Self-employment]. Studia $\mathrm{z}$ Zakresu Prawa, Administracji i Zarządzania UKW, t. 3,s. 36-43 (2013). 